\title{
Article \\ Greening Urban Areas with Decentralized Wastewater Treatment and Reuse: A Case Study of Ecoparque in Tijuana, Mexico
}

\author{
Denise Garcia ${ }^{1,+}$, Gabriela Muñoz Meléndez ${ }^{2}$, Armando Arteaga ${ }^{2}$, Lina Ojeda-Revah ${ }^{2}$ \\ and Natalie Mladenov $1, * \mathbb{D}$ \\ 1 Department of Civil, Construction, and Environmental Engineering, San Diego State University, \\ San Diego, CA 92182, USA; denise.garcia290@gmail.com \\ 2 Departamento de Estudios Urbanos y del Medio Ambiente, El Colegio de la Frontera Norte, \\ Tijuana 22560, Mexico; gmunoz@colef.mx (G.M.M.); aarteaga@colef.mx (A.A.); lojeda@colef.mx (L.O.-R.) \\ * Correspondence: nmladenov@sdsu.edu \\ + Current Address: Department of Civil and Environmental Engineering, University of California, \\ Berkeley, CA 94720, USA.
}

Citation: Garcia, D.; Muñoz Meléndez, G.; Arteaga, A.; Ojeda-Revah, L.; Mladenov, N. Greening Urban Areas with Decentralized Wastewater Treatment and Reuse: A Case Study of Ecoparque in Tijuana, Mexico. Water 2022, 14, 596. https://doi.org/ $10.3390 /$ w14040596

Academic Editors: Fabio Masi, Anacleto Rizzo, Martin Regelsberger and Fulvio Boano

Received: 2 January 2022

Accepted: 11 February 2022

Published: 15 February 2022

Publisher's Note: MDPI stays neutral with regard to jurisdictional claims in published maps and institutional affiliations.

Copyright: (C) 2022 by the authors. Licensee MDPI, Basel, Switzerland. This article is an open access article distributed under the terms and conditions of the Creative Commons Attribution (CC BY) license (https:// creativecommons.org/licenses/by/ $4.0 /)$.

\begin{abstract}
In rapidly growing urban areas, such as Tijuana, Mexico, the presence of urban green spaces (UGSs) can help stem soil erosion, improve infiltration, slow runoff, decrease flooding, reduce air pollution, and mitigate climate change. In many water-scarce parts of the world, where centralized wastewater treatment is not accessible or practical, decentralized wastewater treatment systems (DEWATSs) have the potential to supply the water needed for irrigating UGSs. Here, we first review UGS systems supported by DEWATSs and the water quality guidelines and challenges associated with implementing DEWATSs for urban greening in different countries, including Mexico. We also critically examine the linkages between the lack of UGSs in Tijuana, Mexico, extensive soil erosion, and failing sanitation infrastructure that has led to the infamously poor water quality in the Tijuana River. Tijuana's Ecoparque Wastewater Treatment Facility, a low-energy, aerobic DEWATS, which collects, treats, and discharges residential sewage for localized landscape irrigation, demonstrates how DEWATSs can meet the water demands for urban greening in rapidly urbanizing cities. The aerobic decentralized treatment using a gravity-fed trickling biofilter resulted in a $>85 \%$ removal of chemical oxygen demand and dissolved organic carbon. Prior to treatment facility upgrades, there was a $\sim 2 \log$ reduction in total coliform and Escherichia coli and a $<20 \%$ decrease in ammonia from the influent to final effluent. After the addition of a maturation pond in 2020, the effluent met Mexico standards for irrigation reuse, with a $\sim 4 \log$ reduction in fecal coliforms from the influent to final effluent. Case study results demonstrated the potential for decentralized wastewater treatment to meet effluent standards for landscape irrigation, provide water for urban greening, and prevent pollution in the Tijuana River and other urban waterways.
\end{abstract}

Keywords: decentralized wastewater treatment systems (DEWATSs); urban green spaces (UGSs); Tijuana River; sewage; water reuse; landscape irrigation

\section{Introduction}

Globally, 44\% of household wastewater is not safely treated [1] (UN-Water, 2021), and wastewater collection and treatment have become a challenge, particularly in lowincome urban areas within developing countries, where wastewater may flow untreated to stormwater conveyances or informal drainage channels. It is not uncommon for household effluents, solid waste, human excreta, and liquid discharges from industry and hospitals to be found in surface waters of many urban areas in developing countries. In addition, more people live in urban areas than in rural areas of the world [2], and the median level of urbanization in Latin America and the Caribbean is projected to soon reach 83\% [2]. Rapid 
urbanization, as well as the conversion of formerly rural areas into urban settlements, have modified the land surface in many Latin American cities, including in Mexico [3], resulting in extensive soil erosion and landslides [4]. The problem can be especially disastrous for informal settlements on steep slopes because their construction is not designed to resist landslides or water course damages, and these communities are far more vulnerable to loss of property and loss of life due to erosion and landslides [4]. The notoriously poor water quality of the Tijuana River, Mexico, due as much to erosion and high sediment loads as to its unchecked sewage inputs, has often made international headlines. Urban reforestation and revegetation is one approach that can be implemented to reduce erosion and recover degraded urban landscapes.

There has been increased attention on restoring urban green spaces (UGSs) to take advantage of their multiple benefits. In addition to its benefits for erosion control, studies have demonstrated that the creation or restoration of UGSs can lead to ground-level ozone abatement [5], greenhouse gas mitigation, improvements in water quality, and the provision of habitats for wildlife [6], as well as improved public health and educational benefits [7]. Yet, in water-scarce environments, uncertain or unreliable water supplies pose a major challenge for the maintenance of UGSs. Many arid, urban areas lack water supplies to meet even the most essential domestic and commercial demands and, therefore, applying water for uses such as landscape irrigation is not a priority [6]. Under these conditions, wastewater treated to appropriate standards can provide a consistent and reliable source of water for irrigating UGSs.

For the most part, nonpotable water reuse programs for landscape irrigation are more common in developed countries, where centralized wastewater treatment is most common due to economies of scale that favor large facilities [8,9], and landscape irrigation using reclaimed water is less commonly reported in low-income settings. Decentralized wastewater treatment systems (DEWATSs) with nonpotable water reuse are increasingly being implemented worldwide, but especially in developing countries $[10,11]$, where their lower energy use and simpler designs, compared to centralized treatment, are attractive. DEWATSs that treat wastewater and provide recycled water in close proximity to the source can reduce energy use and greenhouse gas emissions compared to centralized treatment plants [12]. Despite the potential benefits of DEWATSs for nonpotable water reuse, especially in water-scarce settings, studies describing DEWATS performance and provision of recycled water for irrigating UGSs are lacking.

To better understand how decentralized water reuse systems can be successfully utilized for urban greening, the main objectives of this study were to: (1) review the literature regarding decentralized water reuse for urban greening in water-scarce environments around the world, (2) highlight important challenges in decentralized water reuse, and (3) evaluate the performance of a DEWATS where water is applied for the irrigation of UGSs. The Ecoparque Wastewater Treatment Plant, a DEWATS in Tijuana, Mexico, is reviewed here as a case study, and performance monitoring was conducted at Ecoparque before and after treatment plant upgrades. Our review and case study evaluation provide new information on decentralized wastewater treatment systems operating under realworld conditions that may inform the wider implementation of DEWATSs in water-scarce environments.

\section{Methods}

\subsection{Data Collection and Literature Review}

Our review searched papers published primarily since 2000 on the topic of decentralized wastewater treatment and reuse for urban greening. Keywords that were utilized in the searches were: decentralized water reuse, decentralized wastewater treatment, urban greening, DEWATS, reclaimed wastewater, recycled wastewater, landscape irrigation, and urban green spaces. The main search engines used to review the literature were Web of Science, Scopus, and Google Scholar. 


\subsection{Ecoparque Case Study}

As an example of a decentralized wastewater treatment plant that actively conducts onsite water reuse for landscape irrigation, the performance of the Ecoparque Wastewater Treatment Plant was studied in greater depth. The environmental education programs of Ecoparque have been reviewed by Barrera [13] and a sustainable indicator analysis was performed for Ecoparque [14]; however, detailed performance analysis of each unit of the treatment plant and the ability to meet water reuse standards for landscape irrigation have not yet been reported on. For more than three decades, Ecoparque has been treating wastewater from central Tijuana and using some of the effluent to meet irrigation needs onsite and returning the remainder back to the sewer main (what is called a "sewer mining" scenario). A wastewater supply to Ecoparque is possible through an agreement between Tijuana State Public Services Comission (Comisión de Servicios Públicos de Tijuana (CESPT)) and El Colegio de la Frontera Norte (El Colef) in Tijuana. A description of the treatment plant and the sampling and analyses conducted for this study follows.

\subsubsection{Study Site}

Domestic wastewaters arrive at Ecoparque from a 52 hectare settlement within 80 blocks (21 clusters of homes with 2090 households, of which $~ 86 \%$ are occupied) that is home to 6193 people and 153 small businesses. Ninety percent of households have a water supply and $85 \%$ are connected to the sewer system. Wastewater flows to Ecoparque by gravity and $\sim 5 \mathrm{~L} / \mathrm{s}$ is intercepted via a 30 inch-dia $(0.76 \mathrm{~m}$-dia) collector, which conveys water to a desander channel and on to a distribution tank. From the distribution tank, $\sim 3 \mathrm{~L} / \mathrm{s}$ flows by gravity to a trickling biofilter and the remainder is returned to the sewer main (Figure S1). During the study period, $20-40 \%$ of the biofilter effluent was recirculated back to the influent line of the trickling biofilter to increase the solids retention time (SRT) of this biological treatment unit. After passing the clarifier, the effluent was introduced to a horizontal flow subsurface wetland followed by a planted wetland. In 2020, a maturation pond was added at the end of the treatment plant. Figure 1 shows locations and elevations of the process units, which were sited to allow for gravity flow. The full treatment train and photos of sampling points are shown in Supplemental Figure S1.
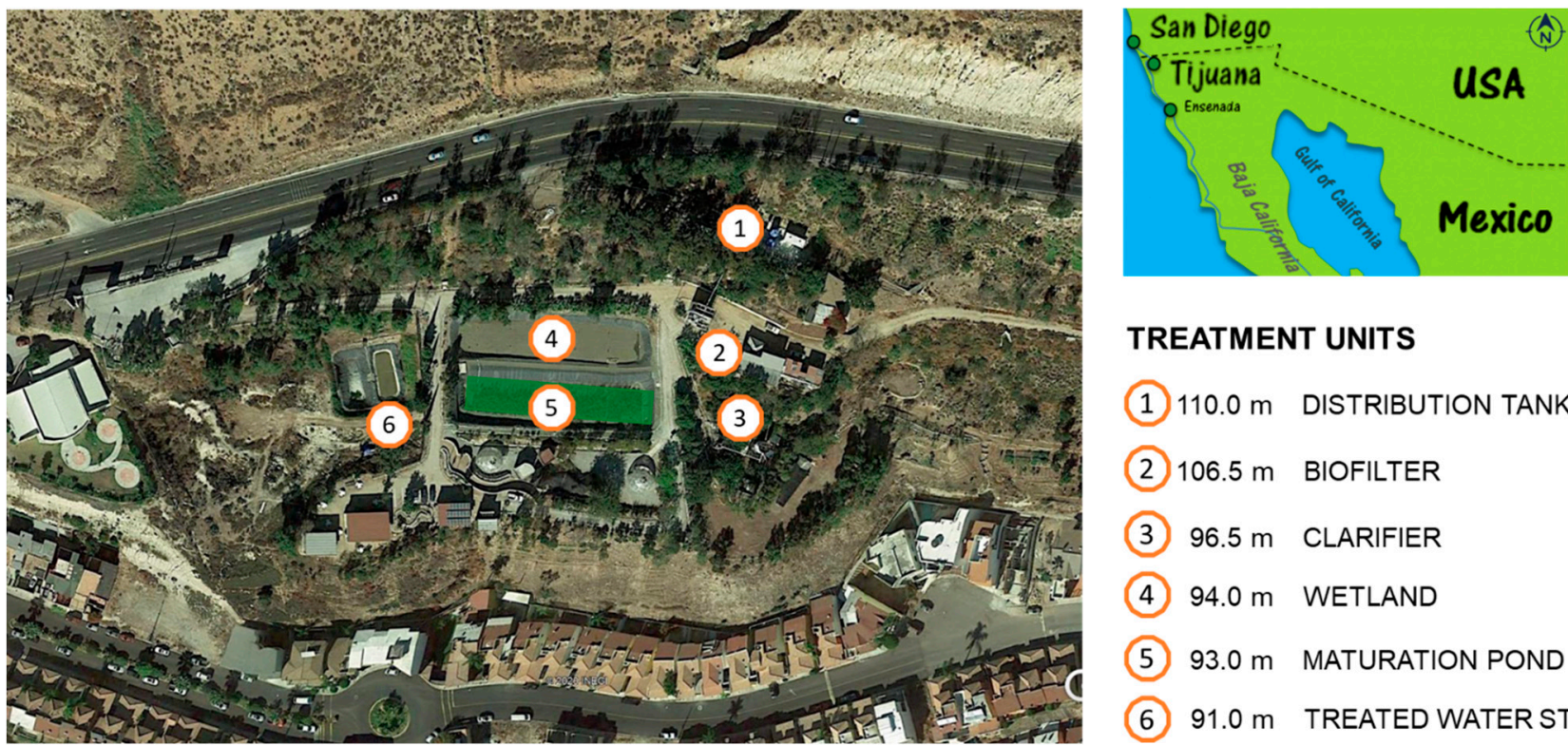

\section{TREATMENT UNITS}

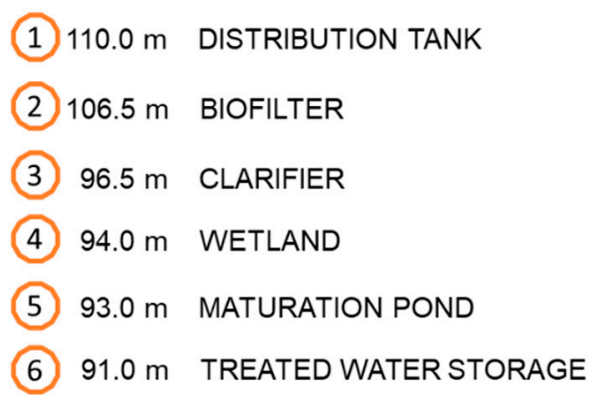

Figure 1. Aerial photograph showing Ecoparque, its vegetated areas, and main treatment units (numbered and corresponding outlet elevations are given) and map of Tijuana and San Diego at the US-Mexico border. 


\subsubsection{Sample Collection}

Wastewater samples were collected as grab samples $(500 \mathrm{~mL})$ every two hours and composited into two sterile, plastic $500 \mathrm{~mL}$ bottles to make true duplicate samples. Samples were collected from five treatment train locations during 5 visits that occurred between the months of August 2019 and February 2020: influent (distribution tank), biofilter effluent, clarifier effluent, wetland effluent, and clarifier sludge.. Within $24 \mathrm{~h}$ of collection, samples were hand-carried in a cooler box (at $\sim 4^{\circ} \mathrm{C}$ ) across the US-Mexico border and transported to San Diego State University (SDSU) for analysis. After treatment plant upgrade and installation of the maturation pond, samples were also collected from the maturation pond effluent on four dates in August 2020 and Septemeber 2021. Due to pandemic (COVID-19) restrictions, these samples were not analyzed at SDSU, and were sent to a certified lab for water quality analysis.

\subsubsection{Water Quality Analyses}

Water quality parameters, including $\mathrm{pH}$ and electrical conductivity, dissolved oxygen, and temperature, were measured on the same day as grab sampling using a Hanna HI-9829 multi-parameter portable meter (Hanna Instruments, Woonsocket, RI, USA). Water samples were analyzed at San Diego State University for chemical oxygen demand (COD) and soluble COD concentrations (sCOD) using the HACH COD TNT kit and read with a HACH DR3900 spectrometer. For sCOD, samples were first filtered using a $0.7 \mu \mathrm{m}$ pre-combusted $\left(500^{\circ} \mathrm{C}\right)$ Whatman glass-fiber filter. Samples for nutrient analyses (ammonia, nitrate, and phosphate) were frozen and analyzed within a week of sample delivery using HACH TNT nitrite, nitrate, ammonia, and phosphate kits and a HACH DR3900 spectrometer.

Dissolved organic carbon (DOC) and total dissolved nitrogen (TDN) samples were filtered with a $0.7 \mu \mathrm{m}$ pre-combusted $\left(500^{\circ} \mathrm{C}\right)$ Whatman glass-fiber filter. Samples were analyzed using the Shimadzu TOC-L total organic carbon analyzer for DOC (measured as nonpurgeable organic carbon) and TDN using a high-temperature combustion method. TDN and DOC standard solutions were included during analyses to ensure instrument reading accuracy. Samples were diluted to ensure readings were within the standard curve, distribution tank (1:10 or 1:20), biofilter (1:10), clarifier (1:10), and wetland (no dilution). Duplicate samples were analyzed at each sampling location.

Fecal indicator bacteria (FIB; total coliforms and Escherichia coli) concentrations were determined using the IDEXX Colilert-18 test with the IDEXX Quanti-Tray 2000 system on diluted, unfiltered samples within $24 \mathrm{~h}$ of sample collection. Percent removals of chemical and biological constituents were calculated as follows in Equation (1):

$$
\% \text { removal }=\left(C_{\text {in }}-C_{w}\right) / C_{\text {in }}
$$

where $C_{\text {in }}$ represents the concentration in the influent and $C_{w}$ represents the concentration in the final effluent (wetland effluent prior to upgrade and maturation pond effluent after upgrade).

\section{Results and Discussion}

\subsection{DEWATS for Wastewater Treatment and Local Reuse}

Globally, more than $50 \%$ of the world's waterways are polluted with untreated wastewater $[15,16]$, and only $\sim 40 \%$ of the global population uses improved sanitation with safe management of excreta [15]. Conventional centralized WWTPs that employ secondary treatment and nutrient removal provide high-quality effluent. However, these large centralized systems are often infeasible in many parts of the world. The high capital costs of centralized wastewater treatment systems and challenges associated with training personnel and operating and maintaining treatment units have resulted in failures of such systems or the lack of adoption [11,17], leaving untreated wastewater to flow instead to receiving waters. For example, in India, where centralized systems treat only a portion of the urban wastewater generated and on-site systems are difficult to implement in densely 
populated settlements, only $37.6 \%$ of wastewater receives treatment prior to release into the environment [11].

Similarly, in Mexico, rapid expansion and insufficient sanitation coverage have led to the deteriorating quality of surface water and concerns over public health protection [18]. Informal settlements, which were established without any formal town planning, are commonplace in Mexico and may comprise more than $50 \%$ of urban areas [19]. Informal settlements have no provision for urban services, including no formal sanitation, with excreta entering the environment through discharge to low points on properties or gullies. Indeed, along the US-Mexico border, $16 \%$ of the total population is not served with respect to public water systems and sewered wastewater treatment systems [20]. By late 2010, $>70,000$ households did not have water for human consumption and $>584,000$ were not connected to the sewage network [21].

Even where sewer connections exist for many homes in central parts of Tijuana, Mexico, reports have shown that failing infrastructure leads to domestic and industrial wastewater flowing untreated into creeks (arroyos) or other drainage channels [22,23]. These waters eventually make their way into the Tijuana River, which acts as an open combined sewer (for both wastewater and stormwater) that flows to the Comisión International de Limites y Aguas, Sección Mexicana (CILA) pumping station at the US-Mexico border, from which up to 28 million gallons per day (MGD) is pumped to the San Antonio de Los Buenos treatment plant and sent untreated (due to inoperation of the treatment plant) to the Pacific Ocean [23]. When flows are higher than 28 MGD or when the CILA pump station fails, flows containing untreated wastewater, sediment, and trash enter the USA via the Tijuana River [23].

Small- and medium-sized wastewater treatment plants and neighborhood- or even household-scale wastewater treatment systems are being considered as an alternative to constructing costly centralized wastewater treatment systems [17], especially in communities that lack access to water and sanitation or in locations that are too remote to support centralized water systems. DEWATSs are considered water-borne sanitation and treatment systems and, therefore, are not noticeably different from conventional centralized sewerage at the user interface. In India, there has been an increased uptake in DEWATSs for treating domestic wastewater (77 new DEWATS facilities were installed between 2017 and 2019), with negligible energy and chemical consumption and with treated water applied locally for irrigation of open areas [11]. The Bremen Overseas Research and Development Association (BORDA), a nongovernment organization (NGO), has been a leader in constructing DEWATS plants for biogas recovery, wastewater treatment, and water reuse worldwide, including several that use treated effluent for the irrigation of urban open spaces. Indonesia has, by far, the largest number (1950) of anaerobic DEWATSs installed by BORDA, compared to 253 in India, and 161 in Lesotho as of 2017 [24].

To facilitate the appropriate siting of DEWATSs in a community, some research has utilized an optimization modeling approach. Sitzenfrei and Raunch [25] used city-scale analysis aided with a GIS-based approach of sensitivity analysis on water management scenarios to model the transition from centralized to decentralized wastewater treatment systems. Sustainable network infrastructure planning (SNIP), which optimizes the centralized network infrastructures of wastewater treatment plants and sewage systems based on economies of scale, has also been applied [26], as well as multiobjective approaches that consider affordability and resilience in the optimization of decentralized sewage networks [27]. Two optimization models were recently applied to simulate the integration of DEWATSs for nonpotable water reuse into existing sewerage systems and showed that the decentralized approaches achieved reductions in the cost of procuring water and in the demand for freshwater, compared to existing approaches [28]. Given that DEWATSs are often gravity-fed, the energy demand is much lower than for conventional centralized treatment systems [11]. Furthermore, anaerobic treatment elements (biogas dome, anaerobic baffled reactors (ABR), anaerobic filters (AF), and anaerobic digesters (AD)) found in many DEWATS have the potential for net-zero energy use or even to be energy-positive. Therefore, DEWATSs can 
reduce or eliminate the currently high-energy demands from the water and wastewater treatment sector. For example, in the USA, water and wastewater treatment consumes 3\% of all electrical power produced [29], and in California, water and wastewater treatment represents up to $20 \%$ of the State's electricity demand [30]. Despite the many benefits of DEWATSs, decentralized systems still require support and maintenance of technology, and the burden of maintaining DEWATSs should not fall on the communities in which they are located. These important considerations for DEWATSs are covered in greater detail, specifically for the case of Tijuana, Mexico, in subsequent sections. Next, we highlight scenarios where DEWATSs, with water reuse located near the point of treatment, are able to fill the increasing need for nonpotable purposes, such as landscape irrigation.

\subsection{Watering of Urban Green Spaces}

There has been increased attention to adding or restoring UGS due to their multiple benefits, which include combating soil erosion, improving mental well-being, reducing the impacts of climate change, ozone abatement, enhancing water quality, and providing habitat for wildlife [5,6]. Urban green spaces significantly affect the regional micro-climate and contribute to the modulation of climatic extremes and improvement of the hydrological cycle $[31,32]$. At the same time, issues with gentrification and lack of community engagement in urban greening decisions have also been exposed in U.S. urban greening efforts [33], and inclusive and community-based approaches for policies related to UGS installation are needed. On the other hand, low-income communities in the USA have had significantly less access to UGSs than more affluent communities, which reflect environmental injustice issues faced by lower-income communities and communities of color [34].

Naturally, UGSs require consistent and reliable water sources, which is an important challenge in water-scarce regions. For example, in India, the poor and irregular watering of UGSs was found to contribute substantially to deteriorating UGSs in urban areas [6]. Therefore, in water-scarce settings, from California and Florida in the USA to South Africa, Australia, and Saudi Arabia [35-37], green spaces have been increasingly supported by irrigation with centrally treated, reclaimed water, meeting effluent standards for water reuse. Despite its wide use in high-income countries, large-scale landscape irrigation with centrally treated wastewater (i.e., recycled or reclaimed water) requires high capital costs for pumps and a water distribution system that is separate from drinking water distribution networks (e.g., purple-colored pipe network in southern California, USA). Such systems are far less accessible in lower-income countries and developing communities.

Despite the widespread use of DEWATSs for local water reuse in many countries (discussed previously), there is a dearth in the literature regarding decentralized applications of treated wastewater, but brochures and nongovernmental organization (NGO) reports do provide some case study examples. For example, in Lesotho, effluent from the ABR-type DEWATS supports the greening of gardens and vegetation for hundreds of households [38]. In India, the Consortium for DEWATS Dissemination (CDD) Society reported several projects with effluent treated to meet guidelines for landscape irrigation. In Pondicherry, India, DEWATS-treated effluent $\left(\sim 300 \mathrm{~m}^{3} / \mathrm{d}\right)$ from a hospital received additional UV treatment for pathogen removal in a polishing pond, making it suitable for landscape irrigation onsite [39]. Effluent from the DEWATS of the urban Pristine Temple Tree Apartments in Bangalore, India is reused for gardening and landscaping [39]. In waterscarce areas of China, cities with rapid urban expansion are also considering DEWATSs for wastewater treatment and reuse of treated effluent for irrigating newly developed housing areas, where high green coverage is often required for both commercial value and living condition improvements [31].

Anaerobic treatment systems are more commonly implemented worldwide for decentralized treatment due to the much lower energy and maintenance requirements compared to aerobic systems. Nevertheless, aerobic treatment units (ATUs), such as trickling filters, media filters, and sand filters, have been utilized in North America [40-42]. Aerobic treatment produces oxidized effluents, which is beneficial for meeting some requirements for 
water reuse for landscape irrigation, such as in California, USA [43]. Decentralized ATUs have been employed in both urban and rural areas for landscape irrigation in the USA, such as in building-scale systems in the Solaire building in New York City and in Piperton, Tennessee's septic tank-trickling filter treatment [42].

\subsection{Guidelines and Challenges for DEWATS Reuse for Landscape Irrigation}

Legislation that mandates water quality standards for effluent used for landscape irrigation is critical to the protection of public health. In California, USA, the California Code of Regulations [43] specifies the treatment type and benchmarks, which are limits on total coliform concentrations, for different types of surface irrigation: (1) disinfected tertiary treatment for unrestricted irrigation, such as for edible food crops, parks and playgrounds, school yards, and residential landscaping, and unrestricted access to golf courses, and (2) undisinfected tertiary treatment for restricted irrigation, such as for cemeteries and freeway landscaping, and (3) undisinfected secondary treatment for other unrestricted uses, such as vineyards, non-food-bearing trees, and ornamental nurseries. This prescribed treatment, which, in all cases, requires the wastewater to be oxidized and filtered, is an impediment to the use of alternative wastewater treatment that may achieve high-quality effluent with anaerobic treatment.

In other countries, effluent water quality limits must be met for landscape irrigation without requiring specific treatment techniques. Table 1 shows current water quality limits for China, India, and Mexico, as an example. In Mexico, water is considered a public resource and is administered by the National Water Commissions through the National Water Law [44]. There are two articles in the Mexican Constitution-Article 27, which provides guidelines based on types of water bodies, and Article 115, which assigns responsibility to the local government to provide a drinking water supply, sewerage, and sanitation services, and to operate and maintain water infrastructure [44]. The latest proposed guidelines for the reuse of water for green areas in Mexico are also given in Table 1.

Table 1. Water reuse limits (as monthly means) for landscape irrigation in different countries or regions.

\begin{tabular}{|c|c|c|c|c|}
\hline Parameter & China $^{1}$ & India $^{2}$ & Mexico Current Limits ${ }^{3}$ & Mexico Proposed Limits 4 \\
\hline Temperature $\left({ }^{\circ} \mathrm{C}\right)$ & - & - & 35 & 35 \\
\hline $\mathrm{pH}$ & $6.0-9.0$ & $5.5-9.0$ & - & $6.5-8.5$ \\
\hline Electrical conductivity & - & 2250 & - & - \\
\hline Grease and oil (mg/L) & - & - & 50 & 15 \\
\hline $\operatorname{TDS}(\mathrm{mg} / \mathrm{L})$ & 1000 & - & 30 & - \\
\hline TSS (mg/L) & 10 & 200 & 30 & 30 \\
\hline $\mathrm{BOD}(\mathrm{mg} / \mathrm{L})$ & 20 & 100 & 50 & - \\
\hline $\mathrm{COD}(\mathrm{mg} / \mathrm{L})$ & 50 & - & - & 60 \\
\hline $\operatorname{TOC}^{5}(\mathrm{mg} / \mathrm{L})$ & - & - & - & 15 \\
\hline $\mathrm{TN}(\mathrm{mg} / \mathrm{L})$ & 0.5 & - & - & NA \\
\hline $\mathrm{TP}(\mathrm{mg} / \mathrm{L})$ & 0.5 & - & - & NA \\
\hline Helminth eggs (eggs/L) & $\leq 2$ & - & $<5.0$ & 1 \\
\hline Fecal coliforms (MPN/100 mL) & $\leq 100$ & - & 1000 & 1000 \\
\hline Enterococci ${ }^{5}(\mathrm{MPN} / 100 \mathrm{~mL})$ & - & - & - & 1000 \\
\hline SAR & 9 & 26 & - & - \\
\hline $\operatorname{Arsenic}(\mathrm{mg} / \mathrm{L})$ & 0.05 & - & 0.100 & 0.2 \\
\hline Boron $(\mathrm{mg} / \mathrm{L})$ & - & 2.0 & 0.100 & - \\
\hline Cadmium (mg/L) & 0.01 & - & 1.000 & 0.05 \\
\hline Cyanide (mg/L) & - & - & 4.000 & 2 \\
\hline Copper $(\mathrm{mg} / \mathrm{L})$ & - & - & 0.500 & 4 \\
\hline Chromium (mg/L) & 0.1 & - & 0.005 & 0.5 \\
\hline
\end{tabular}


Table 1. Cont.

\begin{tabular}{ccccc}
\hline Parameter & China $^{\mathbf{1}}$ & India $^{\mathbf{2}}$ & Mexico Current Limits $^{3}$ & Mexico Proposed Limits $^{\mathbf{4}^{2}}$ \\
\hline Mercury (mg/L) & 0.001 & - & 2.000 & 0.005 \\
Nickel (mg/L) & - & - & 0.200 & 2 \\
Lead (mg/L) & 0.2 & - & 10.00 & 0.5 \\
Zinc (mg/L) & - & - & 0.100 & 10 \\
\hline
\end{tabular}

${ }^{1}$ (GB/T 25499-2010) (Chinese Standard, 2010), referenced in [45]. ${ }^{2}$ limits for irrigation, industrial cooling, and waste disposal [46]. Standards set in 1986 cover, in total, 40 parameters, which are not depicted in this table. ${ }^{3}$ PROY-NOM-001-ECOL-1996 [47] (1997). ${ }^{4}$ PROY-NOM-001 SEMARNAT-2017 proposed limits for water reuse for green areas [48]. ${ }^{5}$ For Mexico, TOC and enterococci are only analyzed in lieu of COD and E. coli if water contains $>1000 \mathrm{mg} / \mathrm{L}$ chloride. Dash $=$ no standard exists for the parameter.

Despite regional prompts (e.g., European Union guidelines for water reuse) and country- or local-scale efforts to introduce water reuse guidelines, many countries still lack proper regulations and policies, as well as enforcement of regulations. The lack of clear legislation creates uncertainty for investment in these systems and can pose further obstacles due to the lack of clarity about responsibilities and liabilities, and issues of entitlement and ownership of recycled water and wastewater [49].

The lack of enforcement of effluent water quality standards for water reuse is a challenge that has also been noted in many studies [50-53]. In some cases, it has been suggested that unjustifiably strict legislation can lead to unsafe water reuse, due to the high costs of treatment and monitoring [50,53]. In Mexico, the issue of a lack of enforcement is coupled to a lack of maintenance of decentralized systems, which results in poor effluent water quality that can lead to public health risks for communities and mistrust of DEWATSs. In Mexico, there are many communities (fraccionamientos) that rely on decentralized wastewater treatment. These walled neighborhoods have small (0 to $25 \mathrm{~L} / \mathrm{s})$ wastewater treatment plants installed by the land developer, which commonly comprise either activated sludge with an extended aeration (EA) or stabilization pond system. There have been mixed results regarding the operation of such facilities. Failure of the systems is common, due to (1) costs related to energy consumption (as aeration for EA systems exerts nonnegligible energy demands), (2) costs to manage sludge, and (3) costs to operate above capacity, with only $25 \%$ operating as intended. Most systems are also challenged by poor energy efficiency and the inability to comply with water quality standards [54].

\subsection{Tijuana Case Study}

Tijuana, Mexico is a rapidly urbanizing city that has experienced rapid growth, with a five-fold increase in population between 1980 and 2020 [55]. In Mexico, more than 90\% of the population is connected to a sewage system or septic system; however, only $\sim 57 \%$ of the collected wastewater receives treatment [56]. Likewise, our calculations show that $\sim 90 \%$ of water supplied to Tijuana residents for nonagricultural uses is conveyed to a treatment plant, but that $>45 \%$ of the conveyed water does not actually receive treatment. In addition, failures in sewage conveyance result in the use of rivers and streams, including the Tijuana River, as open channels to convey wastewater. Sewage pollution of the Tijuana River has been an issue dating back to the mid-1920s, with the Tijuana Valley Sanitation Project of 1938 being the first binational effort to address sewage pollution of the Tijuana River. Sewage infrastructure was not able to keep pace with the rapid urbanization, and, to this day, the Tijuana River functions mainly as an open sewer conveyance for treated and untreated wastewater from the City of Tijuana. Presently, the Tijuana River receives a mixture of treated effluent from the Herrera and La Morita wastewater treatment plants in eastern Tijuana and from untreated wastewater that flows into the Tijuana River from many creeks (arroyos). The sewage infrastructure inadequacies have created recurring sewage pollution problems on both sides of the California-Mexican border.

In addition to its untreated wastewater flows, the Tijuana River also receives substantial inputs of sediment, resulting from soil erosion, especially during storm events. Soils in 
Tijuana and parts of southern California have high permeability and poor water retention, making them unstable and susceptible to erosion [4]. The increased occupation of the urban periphery in Tijuana, Mexico post-1940 has resulted in extensive bare surfaces and rill and gully formation on unpaved roads that generates large volumes of sediment $[57,58]$. In Mexico, the legal framework for site development requires an impact assessment, which allows for natural vegetation to be relocated elsewhere. Many developers use "ice plants" or other inexpensive and readily available plants to afforest open spaces to meet the legal requirement. However, more often than not, inadequate maintenance and water availability results in die-off of the afforested site and subsequent soil erosion [3].

Recent research has shown that the sediment mobilized by channel erosion in Tijuana was responsible for $\sim 25-40 \%$ of the total sediment budget for the Tijuana River watershed and contributed directly to sediment inputs to the impaired Tijuana Estuary [59]. These sediment loads also impede pump operations of the CILA pump station [23]. Moreover, people with the highest rates of poverty settle (often informally) onto steep slopes unsuitable for construction and with high rates of erosion and risk of landslides [60]. That is why Ojeda and Ochoa [4] suggested landscape irrigation be used to stabilize slopes steeper than $35 \%$ and in natural water drainages, where urban construction is prohibited by law due to risk factors. Using satellite imagery from 2012 and 2013, Ojeda and Ochoa [4] determined that this strategy would extend the $0.14 \%$ urban green space coverage in the urban area by an additional $\sim 15 \%$, while contributing to reduced risks associated with landslides and floods. Urban reforestation and revegetation with reused water can improve soil stability [14] and reduce landslide risk and vulnerability of human settlements.

Despite the needs for urban greening in Tijuana, the city had a very low density of public parks in 2018, with a provision of only $1.4 \mathrm{~m}^{2}$ per inhabitant [3]. These areas are also not equally distributed within the city. Huizar and Ojeda-Revah [61] found that in 2010 , within a radius of $400 \mathrm{~m}$ around public parks, just $37.5 \%$ of the population had access to $3 \mathrm{~m}^{2}$ of public park per inhabitant; the rest of the population did not have public park access. This value is well below the World Health Organization recommendation for UGS density of $9 \mathrm{~m}^{2} /$ person. Meanwhile, the neighboring city of San Diego, USA had $\sim 32 \mathrm{~m}^{2}$ /person in its most park-poor areas, which were also the areas with the highest concentrations of low-income households and people of color [62].

\subsection{Ecoparque Decentralized Wastewater Treatment for Landscape Irrigation}

\subsubsection{Ecoparque Background}

Ecoparque is a decentralized wastewater treatment plant that has been operating for over 28 years, and its effluent irrigates the third largest green space (by land area) in Tijuana, Mexico. The successful operation of Ecoparque may be due in part to its operation by El Colegio de la Frontera Norte, which supports onsite technical staff and periodic maintenance, as well as numerous research projects, which have resulted in beneficial upgrades to the treatment plant. Ecoparque treats $\sim 3 \mathrm{~L} / \mathrm{s}$ of residential and commercial wastewater from a $\sim 5$ ha sewershed in Tijuana, Mexico, providing secondary treated effluent to irrigate vegetated landscape on the facility's property. Ecoparque is also an educational facility, which provides educational outreach to university, K-12 groups, and neighbors and conducts diverse research and training.

It is worth noting that due to the mainly gravity-fed treatment processes, energy use at Ecoparque is very low (at $4947.9 \mathrm{KWh} /$ year and $0.0052 \mathrm{kWh} / \mathrm{m}^{3}$ for electricity usage only). Energy is used primarily for the pumping of clarifier effluent to the trickling biofilter, pumping of biosolids to the municipal sewer line for discharge, powering of irrigation systems, and the operations of a guardhouse and two buildings onsite. Pumping requirements are low due to the siting of Ecoparque at a lower elevation than its sewershed so that water arrives to the site via gravity and is conveyed between most treatment units by gravity. Compared to the high energy consumption at conventional activated sludgecentralized WWTPs [63], which can be more than $2.0 \mathrm{kWh} / \mathrm{m}^{3}$ for just aeration alone [64], 
the three orders-of-magnitude lower energy requirement of Ecoparque's treatment systems is advantageous.

The establishment of Ecoparque in 1987 had important urban greening outcomes for the area, which had previously been almost devoid of vegetation and had suffered from erosion problems (Figure 2, left). To reforest the steep (30-40\% slope) and barren hillside, Ecoparque staff hydro-seeded the soils and utilized various reforestation efforts using wastewater, treated onsite, for irrigation. Twenty years later, half of the area ( $3 \mathrm{ha})$ became vegetated and redeveloped as an urban park, mainly for research and educational purposes (Figure 2, right). Since 2007, the vegetated area has remained approximately the same, but more native plant species have been introduced.
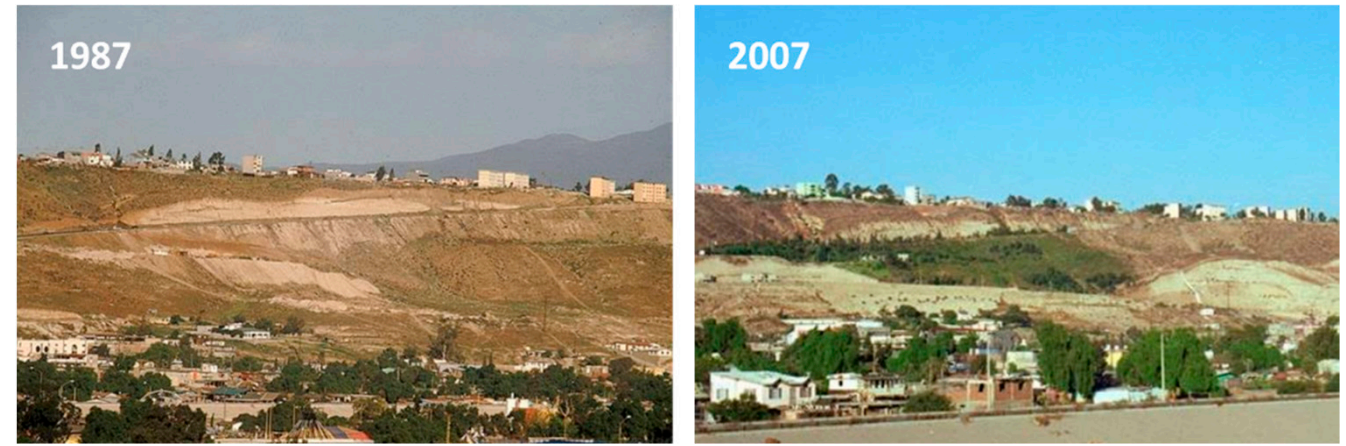

Figure 2. Photographs of the hillslope on which Ecoparque is situated in Tijuana, Mexico. Left: barren hillslope in 1987; Right: reforested hillslope using locally treated reclaimed wastewater.

\subsubsection{Water Quality Prior to Upgrade}

Effluent requirements for urban greening at Ecoparque fall under the water quality standards for landscape irrigation in Mexico (Table 1). The removal of constituents in different parts of the treatment train was investigated in 2018-2019, prior to the WWTP upgrade, which started at the end of 2019. The removal of organic constituents was particularly high, with an $88 \%$ removal of DOC observed throughout the treatment train, resulting in effluent DOC concentrations of $10.7 \pm 3.0 \mathrm{mg} / \mathrm{L}$, with most of the carbon being removed in the trickling biofilter (Table 2). There are no current standards for DOC or total organic carbon (TOC) for landscape irrigation, but this value is within the water quality standards in the proposed document (TOC $<15 \mathrm{mg} / \mathrm{L}$ ) for reuse of wastewater for landscape irrigation in Mexico (Table 1). The preferential degradation of dissolved organic matter containing more labile and proteinaceous compounds was observed primarily in the biofilter and continued through the treatment train. The chemical characterization of organic compounds (Table 2) using metrics from optical spectroscopy, such as the specific UV absorbance (SUVA), fluorescence index, and humification index, were used to evaluate DOC degradation (Supplementary text and Supplementary Figures S2 and S3). 
Table 2. Mean values and standard deviations for basic water quality parameters, inorganic constituents, and organic constituents for monthly samples collected from August 2019 to February 2020 from the Ecoparque WWTP.

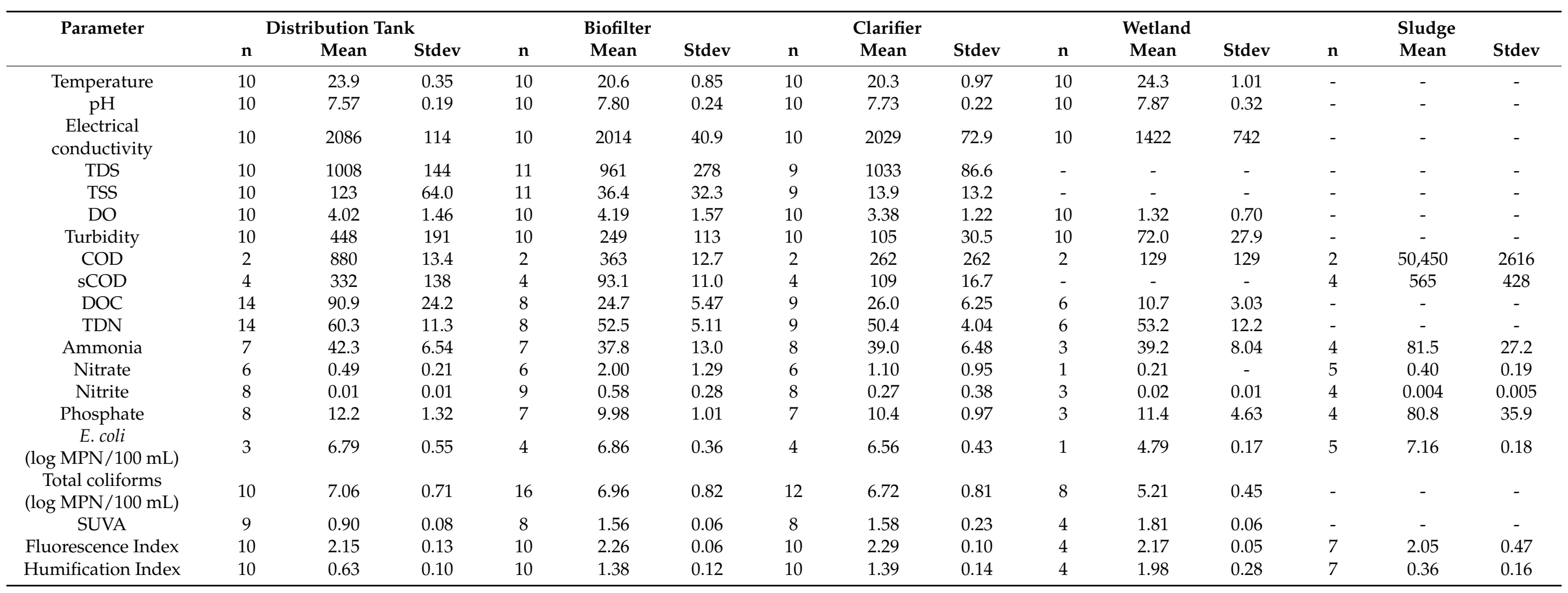


Compared to the substantial removal of organic compounds, there was only a $6 \%$ removal of phosphate and $7.5 \%$ removal of ammonia throughout the treatment train prior to upgrade (Table 2). Nitrate had the highest degree of removal, at $18.7 \%$, but nitrate concentrations were much lower than those of ammonia, indicating that nitrification did not proceed fully, despite primarily aerobic conditions. In addition, although there is a return flow of clarifier effluent to the influent of the biofilter unit to increase the SRT, the SRT of the biofilter is still probably too low to induce nitrification. As there are no water quality standards for nutrients for landscape irrigation in Mexico (Table 1), the high nutrient concentrations are not currently prohibitive for this water reuse. However, the intended reuse of treated water for irrigation of native plant species and some food crops onsite has necessitated upcoming plans to augment the constructed wetland with plantings of Canna hybrid and other species for nutrient and bacteria removal. Wetland polishing may provide additional benefits by attenuating some trace organic compounds, such as pharmaceuticals and chemicals in personal care products, as was recently demonstrated for a DEWATS operating in South Africa [65].

E. coli concentrations measured in all treatment units were similar to total coliform concentrations, implying that most coliform bacteria, including fecal coliforms, are represented by E. coli in this WWTP. The removal of E. coli and total coliforms between the influent and wetland effluent were $29.4 \%$ and $26.2 \%$, respectively (Table 2 ), with the greatest removal seen in the wetland. The final effluent E. coli concentrations were $65,000 \mathrm{MPN} / 100 \mathrm{~mL}$ ( 4.8- $\log$ MPN/100 mL; Table 3), which is more than an order of magnitude higher than Mexico water quality standards for fecal coliforms (at $1000 \mathrm{MPN} / 100 \mathrm{~mL}$ as the $30 \mathrm{~d}$ average; Table 1). The inability of Ecoparque to meet water quality standards was previously noted by Russell [14], who suggested that if the final water quality could be improved, facilities such as Ecoparque have the potential to augment larger-scale treatment plants. This excess was the main reason for a facility upgrade that occurred in 2020, adding a maturation pond with a $6 \mathrm{~d}$ residence time to the treatment train.

It is worth noting that the E. coli concentration in the effluent before the upgrade was comparable to the typical E. coli concentration in undisinfected effluent of secondary wastewater treatment units utilizing activated sludge, which ranges from $10^{4}$ to $10^{5} \mathrm{MPN} / 100 \mathrm{~mL}[66,67]$. In California, USA, undisinfected effluent of secondary treatment systems, which have utilized oxidation as part of their treatment process, cannot be utilized for landscape irrigation, where the risk of pathogen exposure to humans is high. However, undisinfected secondary effluent is appropriate for the irrigation of non-food-bearing crops and orchards and vineyards, as long as the recycled water does not come into contact with the edible portion of the crop [44]. If disinfection is not practical or economically feasible, these types of "restricted" urban green space irrigation applications could still be part of the water reuse portfolio for cities such as Tijuana.

Table 3. Treatment efficiency of Ecoparque before and after treatment plant upgrades.

\begin{tabular}{|c|c|c|c|c|c|c|c|c|c|}
\hline \multirow{3}{*}{$\begin{array}{l}\text { Water Quality } \\
\text { Parameter }\end{array}$} & \multirow{2}{*}{\multicolumn{3}{|c|}{$\begin{array}{c}\text { Mean Values in Wetland Effluent before } \\
\text { Upgrade } \\
\text { August 2019-February } 2020\end{array}$}} & \multicolumn{6}{|c|}{$\begin{array}{c}\text { Mean Values in Maturation Pond Effluent } \\
\text { after Upgrade }\end{array}$} \\
\hline & & & & \multicolumn{3}{|c|}{ August 2020} & \multicolumn{3}{|c|}{ September 2021} \\
\hline & $\mathbf{n}$ & Mean & Removal & $\mathbf{n}$ & Mean & Removal & $\mathbf{n}$ & Mean & Removal \\
\hline Temperature & 5 & $24.3(1.00)$ & - & 4 & $25.8(2.34)$ & NC & - & - & - \\
\hline $\mathrm{pH}$ & 5 & $7.87(0.32)$ & - & - & - & - & - & - & - \\
\hline Oil and grease & & - & - & 4 & - & - & - & - & - \\
\hline $\mathrm{TSS}(\mathrm{mg} / \mathrm{L})$ & 5 & $13.9(13.1)$ & $89 \%$ & 4 & $51.0(14.8)$ & $\mathrm{NC}$ & 1 & 114 & $93 \%$ \\
\hline $\mathrm{BOD}(\mathrm{mg} / \mathrm{L})$ & 2 & $129^{1}(71.5)$ & $85 \%$ & 4 & $19.7(9.77)$ & NC & 1 & 149 & $83 \%$ \\
\hline $\mathrm{DOC}(\mathrm{mg} / \mathrm{L})$ & 3 & $10.7(3.03)$ & $88 \%$ & - & - & - & - & - & - \\
\hline $\mathrm{TN}(\mathrm{mg} / \mathrm{L})$ & 3 & $53.2(12.2)$ & $12 \%$ & - & - & - & - & - & - \\
\hline $\mathrm{TP}(\mathrm{mg} / \mathrm{L})$ & 3 & $11.4(4.63)$ & $6 \%$ & - & - & - & - & - & - \\
\hline
\end{tabular}


Table 3. Cont.

\begin{tabular}{|c|c|c|c|c|c|c|c|c|c|}
\hline \multirow{3}{*}{$\begin{array}{l}\text { Water Quality } \\
\text { Parameter }\end{array}$} & \multirow{2}{*}{\multicolumn{3}{|c|}{$\begin{array}{c}\text { Mean Values in Wetland Effluent before } \\
\text { Upgrade } \\
\text { August 2019-February } 2020\end{array}$}} & \multicolumn{6}{|c|}{$\begin{array}{l}\text { Mean Values in Maturation Pond Effluent } \\
\text { after Upgrade }\end{array}$} \\
\hline & & & & \multicolumn{3}{|c|}{ August 2020} & \multicolumn{3}{|c|}{ September 2021} \\
\hline & $\mathbf{n}$ & Mean & Removal & $\mathbf{n}$ & Mean & Removal & $\mathbf{n}$ & Mean & Removal \\
\hline Helminth eggs $(\mathrm{HH} / \mathrm{L})$ & & - & - & 2 & $0.2(0)$ & NC & - & - & - \\
\hline E. coli $(\mathrm{MPN} / 100 \mathrm{~mL})$ & 1 & $65,000(19,500)$ & 2.0-log & 4 & $668(1159)$ & 6.4-log & 1 & 430 & 4.7-log \\
\hline $\begin{array}{l}\text { Total coliforms } \\
(\mathrm{MPN} / 100 \mathrm{~mL})\end{array}$ & 4 & $\begin{array}{c}296,000 \\
(456,000)\end{array}$ & $1.85-\log$ & - & - & - & - & - & - \\
\hline Arsenic & - & - & - & 1 & ND & NC & - & - & - \\
\hline Cadmium & - & - & - & 1 & ND & NC & - & - & - \\
\hline Cyanide & - & - & - & 1 & 0.0123 & NC & - & - & - \\
\hline Copper & - & - & - & 1 & 0.0028 & NC & - & - & - \\
\hline Chromium & - & - & - & 1 & ND & NC & - & - & - \\
\hline Mercury & - & - & - & 1 & 0.00007 & NC & - & - & - \\
\hline Nickel & - & - & - & 1 & ND & NC & - & - & - \\
\hline Lead & - & - & - & 1 & ND & $\mathrm{NC}$ & - & - & - \\
\hline Zinc & - & - & - & 1 & 0.0141 & NC & - & - & - \\
\hline
\end{tabular}

${ }^{1}$ result is COD instead of BOD. NC = influent not measured and removal cannot be calculated; ND = not detected; Dash $=$ data not collected or not applicable.

\subsection{Water Quality after Upgrade}

In 2020, a $660 \mathrm{~m}^{2}(55 \mathrm{~m} \times 12 \mathrm{~m})$ maturation pond with a $\sim 6 \mathrm{~d}$ residence time was added for further polishing of the wetland effluent (Supplemental Figure S4). After this upgrade, Ecoparque effluent met all limits for BOD, Helminth eggs, and trace metals in August 2020. In August 2020 and September 2021, maturation pond effluent exceeded TSS concentration limits (Table 3), likely due to erosion that occurs during the dry summer season when samples are collected. This upgrade also resulted in a major reduction in fecal coliform concentrations. The $30 \mathrm{~d}$ average concentrations fell below the $1000 \mathrm{MPN} / 100 \mathrm{~mL}$ limit and concentrations were below the $240 \mathrm{MPN} / 100 \mathrm{~mL}$ limit for direct contact on 3 out of 4 sampling dates in August 2020 (Table 3).

\subsection{Ecoparque in the Context of Other Treatment Plants in Mexico}

Of the $>2800$ wastewater treatment plants in Mexico in 2015, the majority (55\%) used activated sludge as the principal treatment process, with stabilization lagoons and aerated lagoons representing 18\% [56]. Likewise, in Tijuana, activated sludge is the most common treatment process (representing $\sim 72 \%$ of municipal wastewater treatment) [68]. Of the 7 out of 18 plants in Tijuana that may be considered small or decentralized, treating $<10 \mathrm{~L} / \mathrm{s}$, most (5 out of 7) also employ activated sludge [68]. Therefore, Ecoparque, with the aerated biotrickling filter as its main biological treatment unit, is uncommon. Performance metrics have been reported for only one other DEWATS in the state of Jalisco, Mexico, which combines a septic tank, upflow anaerobic filter, and horizontal flow constructed wetland treatment units to provide $>90 \%$ COD reduction [69], which is similar to the COD removal achieved at Ecoparque.

One important consideration for the multitude of aerobic treatment plants employed in Mexico, including Ecoparque, is the disposal of biosolids as residuals. Life cycle analysis indicated that environmental impacts related to the final disposal of sludge cannot be neglected [70]. At Ecoparque, sludge is returned to the sewer or otherwise disposed, and our performance analysis did not account for its fate or life cycle costs. A life cycle comparison of two DEWATSs in Matamoros, Mexico, one using constructed wetland technology as its main treatment unit, and the other employing an aerobic, activated sludge system found the constructed wetland system to provide lower greenhouse gas emissions and greater economic savings [71]. 


\section{Conclusions}

Global sustainability goals (Target 11.7 under SDG 11, Sustainable Cities and Communities) have asserted that accessibility and inclusiveness in green space provision must be addressed by 2030 [72]. Our review highlighted several projects around the world that have contributed to meeting this goal by using decentralized wastewater reuse systems to support the irrigation of UGSs. For the most part, the DEWATS case studies cited used anaerobic treatment technologies followed by wetlands or polishing ponds for additional pathogen removal, and effluent was used for gardens and landscape irrigation near the point of treatment. However, appropriately sited aerobic decentralized systems, such as Ecoparque, that take advantage of the natural topographic gradients for gravity-fed operations, can also have substantial energy savings over conventional large-scale centralized WWTPs; however, sludge disposal must be considered. Examples of successful DEWATSs in China and India highlighted the potential for DEWATSs to serve as a safe source of water for irrigating urban green spaces, especially in water-scarce areas.

In the Ecoparque case study, we found that minor upgrades to the treatment train, primarily through the addition of the maturation pond, greatly reduced both nutrient and fecal indicator bacteria concentrations and allowed Ecoparque to achieve the necessary pathogen reductions for unrestricted landscape irrigation. Even prior to upgrade, the gravity-fed, low-energy treatment system provided a $\sim 2 \log$ removal of $E$. coli and total coliforms and a $>85 \%$ removal of COD, which is similar to the treatment provided by conventional secondary wastewater treatment plants.

Many wastewater treatment systems in Latin America are centralized, and an increasing body of literature has shown that, without support for regular maintenance and without proper enforcement of effluent standards, these systems will provide less treatment than they were designed for, becoming sources of pollution themselves. In Tijuana, a centralized distribution of recycled water ("purple lines"), similar to the systems used in California, USA, has been mentioned sporadically in the news by different government representatives [73-75]. However, to date, centralized water reuse infrastructure has not been constructed. The current situation, with many wastewater collector pipes in need of repair, and with untreated wastewater contaminating surface waters, is representative of many Latin American cities. As such, municipal wastewater treatment systems in Latin America can benefit from supplemental decentralized systems that provide both treatment and local water reuse opportunities.

Supplementary Materials: The following supporting information can be downloaded at: https: / / www.mdpi.com/article/10.3390/w14040596/s1. S1. Chemical quality of dissolved organic compounds in the Ecoparque treatment train [76-80]. Table S1. List of all wastewater treatment plants in Tijuana ${ }^{1}$ including their maximum capacity and treated volume. Figure S1. Schematic of treatment train and photographs of sampling points for water quality analyses: (a) influent distribution tank, (b) biofilter effluent tank, (c) clarifier tank, (d) wetland effluent tank, and (e) maturation pond. Figure S2. Box plots, showing mean (x), range (whiskers), exclusive median (box), inner points, and outliers of (a) COD concentration, (b) DOC concentration, (c) specific UV absorbance, and (d) humification index in influent (distribution tank) and effluent of each main treatment unit (biofilter, clarifier, and wetland) at Ecoparque WWTP prior to treatment plant upgrade. Humification index values only available for clarifier waste activated sludge. Figure S3. Representative EEMs showing excitation (Ex) and emission (Em) wavelengths and intensities of emission (shown in the colorbar in Raman units) for influent (distribution tank) and effluent of each main treatment unit (biofilter, clarifier, and wetland), and sludge at Ecoparque WWTP prior to treatment plant upgrade. The positions of ubiquitous peaks, A, B, C, and T, are shown in the wetland EEM. Note the higher values of fluorescence intensities for distribution tank and sludge samples. Figure S4. Photographs of installation of the maturation pond and its components.

Author Contributions: D.G.-formal analysis, investigation, funding acquisition, writing; G.M.M.formal analysis, investigation, supervision, project administration, resources, writing; A.A.-formal analysis, investigation, supervision, writing; L.O.-R.-investigation, resources, writing; N.M.- 
conceptualization, formal analysis, funding acquisition, project administration, supervision, methodology, visualization, writing. All authors have read and agreed to the published version of the manuscript.

Funding: This research was funded by the US National Science Foundation (NSF-CBET 1705901) and the SDSU National Institute of Health (NIH) Initiative for Maximizing Student Development (IMSD) program.

\section{Institutional Review Board Statement: Not applicable.}

Informed Consent Statement: Not applicable.

Data Availability Statement: Data available upon request.

Acknowledgments: We thank D. Aponte for assistance with sample collection and transport, and F. Pinongcos, A. Rocha, L. Astete Vasquez, and M. Mueller for assistance with laboratory analyses.

Conflicts of Interest: The authors declare no conflict of interest.

\section{References}

1. UN-Water. Quality and Wastewater. UN-Water. Available online: https://www.unwater.org/water-facts/quality-andwastewater/ (accessed on 8 February 2021).

2. United Nations. World Urbanization Prospects: The 2018 Revision. 2018. Available online: https://population.un.org/wup/ Publications/Files/WUP2018-KeyFacts.pdf (accessed on 14 February 2021).

3. López, E.; Bocco, G.; Mendoza, M.; Duhau, E. Predicting land-cover and land-use change in the urban fringe: A case in Morelia city, Mexico. Landsc. Urban Plan. 2001, 55, 271-285. [CrossRef]

4. Ochoa, Y.; Ojeda-Revah, L. Conservación de vegetación para reducir riesgos hidrometereológicos en una metrópoli fronteriza [Vegetation conservation to reduce hydrometeorological risks on a border metropolis]. Estud. Front. 2017, 18, 47-69. [CrossRef]

5. Kroeger, T.; Escobedo, F.J.; Hernandez, J.L.; Varela, S.; Delphin, S.; Fisher, J.R.; Waldron, J. Reforestation as a novel abatement and compliance measure for ground-level ozone. Proc. Natl. Acad. Sci. USA 2014, 111, E4204-E4213. [CrossRef] [PubMed]

6. Ramaiah, M.; Avtar, R. Urban Green Spaces and Their Need in Cities of Rapidly Urbanizing India: A Review. Urban. Sci. 2019, 3, 94. [CrossRef]

7. Tallis, H.; Bratman, G.N.; Samhouri, J.F.; Fargione, J. Are California elementary school test scores more strongly associated with urban trees than poverty? Front. Psychol. 2018, 9, 2074. [CrossRef]

8. Lundin, M.; Bengtsson, M.; Molander, S. Life Cycle Assessment of Wastewater Systems: Influence of System Boundaries and Scale on Calculated Environmental Loads. Environ. Sci. Technol. 2000, 34, 180-186. [CrossRef]

9. Cornejo, P.K.; Zhang, Q.; Mihelcic, J.R. How Does Scale of Implementation Impact the Environmental Sustainability of Wastewater Treatment Integrated with Resource Recovery? Environ. Sci. Technol. 2016, 50, 6680-6689. [CrossRef]

10. Reynaud, N.; Buckley, C. Field-data on parameters relevant for design, operation and monitoring of communal decentralized wastewater treatment systems (DEWATS). Water Pract. Technol. 2015, 10, 787-798. [CrossRef]

11. Singh, A.; Sawant, M.; Kamble, S.J.; Herlekar, M.; Starkl, M.; Aymerich, E.; Kazmi, A. Performance evaluation of a decentralized wastewater treatment system in India. Environ. Sci. Pollut. Res. Int. 2019, 26, 21172-21188. [CrossRef]

12. Kavvada, O.; Horvath, A.; Stokes-Draut, J.R.; Hendrickson, T.P.; Eisenstein, W.A.; Nelson, K.L. Assessing Location and Scale of Urban Nonpotable Water Reuse Systems for Life-Cycle Energy Consumption and Greenhouse Gas Emissions. Environ. Sci. Technol. 2016, 50, 13184-13194. [CrossRef]

13. Barrera, D.M.R. Programas de Educación Ambiental no Formal. ¿Creando Conciencia o Sólo Informando a la Población? El caso del Programa de Ecoparque, Tijuana, Baja California, 2004-2008. Master's Thesis, El Colegio de la Frontera Norte, Tijuana, Mexico, 2010.

14. Russell, R. Waste not, want not? Evaluating the urban sustainability implications of centralized versus decentralized wastewater treatment in Tijuana, Mexico. Urban. Geogr. 2014, 35, 805-821. [CrossRef]

15. Mara, D. Domestic Wastewater Treatment in Developing Countries; Routledge: London, UK, 2013. [CrossRef]

16. Baum, R.; Luh, J.; Bartram, J. Sanitation: A Global Estimate of Sewerage Connections without Treatment and the Resulting Impact on MDG Progress. Environ. Sci. Technol. 2013, 47, 1994-2000. [CrossRef] [PubMed]

17. Maurer, M.; Rothenberger, D.; Larsen, T.A. Decentralised wastewater treatment technologies from a national perspective: At what cost are they competitive? Water Supply 2005, 5, 145-154. [CrossRef]

18. International Boundary and Water Commission United States and Mexico (IBWC). Report of Transboundary Bypass Flows into the Tijuana River. 2017. Available online: https://www.waterboards.ca.gov/sandiego/water_issues/programs/tijuana_river_ valley_strategy/docs/sewage_issue/2017-04-03_IBWC_Investigative_Report.pdf (accessed on 21 September 2021).

19. Benítez, G.; Pérez-Vázquez, A.; Nava-Tablada, M.; Equihua, M.; Álvarez-Palacios, J.L. Urban expansion and the environmental effects of informal settlements on the outskirts of Xalapa city, Veracruz, Mexico. Environ. Urban. 2012, 24, 149-166. [CrossRef]

20. Hargrove, W.L.; Del Rio, M.; Korc, M. Water matters: Water insecurity and inadequate sanitation in the US/Mexico border region. Environ. Justice 2018, 11, 222-227. [CrossRef] 
21. SEMARNAT EPA. Programa Ambiental México-Estados Unidos: Frontera 2012 Situación de la Región Fronteriza. Reporte de indicadores 2010; 2011. Available online: https:/ /www.epa.gov/sites/production/files/documents/border-2012_indicator-rpt_ esp_0.pdf (accessed on 15 April 2020).

22. Arcadis. Tijuana River Diversion Study: Flow Analysis, Infrastructure Diagnostic and Alternatives Development; North American Development Bank: San Antonio, TX, USA, 2019.

23. HDR. Tijuana River Valley: Needs and Opportunities Assessment; HDR: San Diego, CA, USA, 2020.

24. BORDA. DEWATS Implementation by BORDA; BORDA: Bremen, Germany, 2017.

25. Sitzenfrei, R.; Rauch, W. Investigating Transitions of Centralized Water Infrastructure to Decentralized Solutions-An Integrated Approach. Procedia Eng. 2014, 70, 1549-1557. [CrossRef]

26. Eggimann, S.; Truffer, B.; Maurer, M. To connect or not to connect? Modelling the optimal degree of centralisation for wastewater infrastructures. Water Res. 2015, 84, 218-231. [CrossRef]

27. Zahediasl, A.; Bakhshipour, A.E.; Dittmer, U.; Haghighi, A. Toward Decentralised Sanitary Sewage Collection Systems: A Multiobjective Approach for Cost-Effective and Resilient Designs. Water 2021, 13, 1886. [CrossRef]

28. Dev, A.; Dilly, T.C.; Bakhshipour, A.E.; Dittmer, U.; Bhallamudi, S.M. Optimal Implementation of Wastewater Reuse in Existing Sewerage Systems to Improve Resilience and Sustainability in Water Supply Systems. Water 2021, 13, 2004. [CrossRef]

29. McCarty, P.L.; Bae, J.; Kim, J. Domestic Wastewater Treatment as a Net Energy Producer—Can This be Achieved? Environ. Sci. Technol. 2011, 45, 7100-7106. [CrossRef]

30. California Energy Commission (CEC). Integrated Energy Policy Report; California Energy Commission: Sacramento, CA, USA, 2005.

31. Wang, X.; Chen, R.; Zhang, Q.; Li, K. Optimized plan of centralized and decentralized wastewater reuse systems for housing development in the urban area of Xi'an, China. Water Sci. Technol. 2008, 58, 969-975. [CrossRef] [PubMed]

32. Niraula, R.; Meixner, T.; Norman, L.M. Determining the importance of model calibration for forecasting absolute/relative changes in streamflow from LULC and climate changes. J. Hydrol. 2015, 522, 439-451. [CrossRef]

33. Anguelovski, I.; Brand, A.L.; Connolly, J.J.T.; Corbera, E.; Kotsila, P.; Steil, J.; Garcia-Lamarca, M.; Triguero-Mas, M.; Cole, H.; Baró, F.; et al. Expanding the Boundaries of Justice in Urban Greening Scholarship: Toward an Emancipatory, Antisubordination, Intersectional, and Relational Approach. Ann. Am. Assoc. Geogr. 2020, 110, 1743-1769. [CrossRef]

34. Wendel, H.E.W.; Downs, J.A.; Mihelcic, J.R. Assessing equitable access to urban green space: The role of engineered water infrastructure. Environ. Sci. Technol. 2011, 45, 6728-6734. [CrossRef] [PubMed]

35. Tchobanoglous, G.; Burton, F.L.; Stensel, H.D. Wastewater Engineering: Treatment and Reuse, 4th ed.; McGraw-Hill: New York, NY, USA, 2003.

36. Adewumi, J.; Ilemobade, A.; Van Zyl, J. Treated wastewater reuse in South Africa: Overview, potential and challenges. Resour. Conserv. Recycl. 2010, 55, 221-231. [CrossRef]

37. Pescod, M.B. Wastewater Treatment and Use in Agriculture; Food and Agriculture Organization of the United Nations: Quebec City, QC, Canada, 1992.

38. Pietruschka, B.; Durban, South Africa. Personal communication, 2018.

39. Consortium for DEWATS Dissemination Society (CDD). DEWATS: Decentralised Wastewater Treatment System, an Alternative to Centralized Wastewater Treatment; CDD: Bangalore, India, 2019.

40. United States Environmental Protection Agency. Decentralized Systems Technology Fact Sheet: Types of Filters [Fact Sheet]. 2000. Available online: https:/ / nepis.epa.gov/ (accessed on 15 April 2020).

41. Parten, S.M. Planning and Installing Sustainable Onsite Wastewater Systems; McGraw-Hill Professional: New York, NY, USA, 2010.

42. D'Amato, V.; Moeller, J.; Striano, E. Rethinking decentralized systems: A new tool for sustainable water management. Water Environ. Technol. 2011, 23, 62-66.

43. Title 22 Code of Regulations. In California Code of Regulations; California Water Boards: Sacramento, CA, USA, $2015 ;$ p. 81.

44. Mendoza-Espinosa, L.G.; Burgess, J.E.; Daesslé, L.; Villada-Canela, M. Reclaimed water for the irrigation of vineyards: Mexico and South Africa as case studies. Sustain. Cities Soc. 2019, 51, 101769. [CrossRef]

45. Smith, K.; Guo, S.; Zhu, Q.; Dong, X.; Liu, S. An evaluation of the environmental benefit and energy footprint of China's stricter wastewater standards: Can benefit be increased? J. Clean. Prod. 2019, 219, 723-733. [CrossRef]

46. Schellenberg, T.; Subramanian, V.; Ganeshan, G.; Tompkins, D.; Pradeep, R. Wastewater discharge standards in the evolving context of urban sustainability-The case of India. Front. Environ. Sci. 2020, 8, 30. [CrossRef]

47. Official Mexican Standard NOM-001-SEMARNAT-1996; Maximum Permissible Limits of Contaminants in Wastewaters Discharged to National Waters and Receiving Bodies. Official Journal of the Federation: Mexico City, Mexico, 1997. (In Spanish)

48. Proposed Mexican Standard NOM-001-SEMARNAT-2017; Permissible Limits of Contaminants in Wastewaters Discharged to National Waters and Receiving Bodies. Official Journal of the Federation: Mexico City, Mexico, 2018. (In Spanish)

49. Arora, M.; Malano, H.; Davidson, B.; Nelson, R.; George, B. Interactions between centralized and decentralized water systems in urban context: A review. Wiley Interdisciplinary Reviews. Water 2015, 2, 623-634. [CrossRef]

50. Drechsel, P.; Blumenthal, U.J.; Keraita, B. Balancing health and livelihoods: Adjusting wastewater irrigation guidelines for resource-poor countries. Urban. Agric. Mag. 2002, 8, 7-9.

51. Mazari-Hiriart, M.; Ponce-de-León, S.; López-Vidal, Y.; Islas-Macías, P.; Amieva-Fernández, R.I.; Quiñones-Falconi, F. Microbiological implications of periurban agriculture and water reuse in Mexico City. PLoS ONE 2008, 3, e2305. [CrossRef] [PubMed] 
52. Qadir, M.; Wichelns, D.; Raschid-Sally, L.; McCornick, P.G.; Drechsel, P.; Bahri, A.; Minhas, P.S. The challenges of wastewater irrigation in developing countries. Agric. Water Manag. 2010, 97, 561-568. [CrossRef]

53. Angelakis, A.N.; Gikas, P. Water reuse: Overview of current practices and trends in the world with emphasis on EU states. Water Util. J. 2014, 8, e78.

54. Noyola, A.; Padilla-Rivera, A.; Morgan-Sagastume, J.M.; Güereca, L.P.; Hernández-Padilla, F. Typology of Municipal Wastewater Treatment Technologies in Latin America. Clean-Soil Air Water 2012, 40, 926-932. [CrossRef]

55. Wright, D.; Vela, R.; Ganster, P.; Johnson, H.D. Tijuana River Watershed atlas-Atlas de la Cuenca del Río Tijuana; Wright, R.D., Vela, R., Eds.; Department of Geography, San Diego State University; San Diego State University Press: San Diego, CA, USA, 2005.

56. Comisión Nacional del Agua (CONAGUA). Estadísticas del Agua en México, edición 2016; CONAGUA: Mexico City, Mexico, 2016. (In Spanish)

57. Biggs, T.W.; Atkinson, E.; Powell, R.; Ojeda-Revah, L. Land cover following rapid urbanization on the US-Mexico border: Implications for conceptual models of urban watershed processes. Landsc. Urban. Plan. 2010, 96, 78-87. [CrossRef]

58. Biggs, T.; Taniguchi, K.; Gudino-Elizondo, N.; Langendoen, E.; Yuan, Y.; Bingner, R.; Liden, D. Runoff and Sediment. Yield on the US-Mexico Border, Los Laureles Canyon; EPA/600/R-18/365; U.S. Environmental Protection Agency: Washington, DC, USA, 2018.

59. Taniguchi, K.T.; Biggs, T.W.; Langendoen, E.J.; Castillo, C.; Gudino-Elizondo, N.; Yuan, Y.; Liden, D. Stream channel erosion in a rapidly urbanizing region of the US-Mexico border: Documenting the importance of channel hardpoints with Structure-fromMotion photogrammetry. Earth Surf. Processes Landf. 2018, 43, 1465-1477. [CrossRef]

60. Machado, R.A.; Oliveira, A.G.; Lois-González, R.C. Urban ecological infrastructure: The importance of vegetation cover in the control of floods and landslides in Salvador/Bahia, Brazil. Land Use Policy 2019, 89, 104180. [CrossRef]

61. Huizar, H.; Ojeda-Revah, L. Los Parques de Tijuana: Una perspectiva de justicia ambiental. In Cuando las áreas verdes se transforman en paisaje: La visión de Baja California [When Green Areas Become Landscape: The Baja California Vision]; Ojeda-Revah, L., Espejel, I., Eds.; Colegio de la Frontera Norte: Tijuana, Mexico, 2014; pp. 87-120.

62. San Diego Foundation. Parks for Everyone 2.0: An Update to the Parks for Everyone Report. 2020. Available online: https: //www.sdfoundation.org/wp-content/uploads/2015/10/2010-parkforeveryone_finalsm.pdf (accessed on 15 April 2020).

63. Singh, P.; Carliell-Marquet, C.; Kansal, A. Energy pattern analysis of a wastewater treatment plant. Appl. Water Sci. 2012, 2, 221-226. [CrossRef]

64. Belloir, C.; Stanford, C.; Soares, A. Energy benchmarking in wastewater treatment plants: The importance of site operation and layout. Environ. Technol. 2015, 36, 260-269. [CrossRef]

65. Mladenov, N.; Dodder, N.; Steinberg, L.; Richardot, W.; Johnson, J.; Martincigh, B.; Buckley, C.; Lawrence, T.; Hoh, E. Persistence and removal of trace organic compounds in centralized and decentralized wastewater treatment systems. Chemosphere 2022, 286, 131621. [CrossRef] [PubMed]

66. Łuczkiewicz, A.; Fudala-Ksiązek, S.; Jankowska, K.; Quant, B.; Olańczuk-Neyman, K. Diversity of fecal coliforms and their antimicrobial resistance patterns in wastewater treatment model plant. Water Sci. Technol. 2010, 61, 1383-1392. [CrossRef]

67. Campos, C.J.A.; Avant, J.; Lowther, J.; Till, D.; Lees, D. Levels of Norovirus and E. coli in Untreated, Biologically Treated and UV-Disinfected Sewage Effluent Discharged to a Shellfish Water. J. Water Resour. Prot. 2013, 5, 978-982. [CrossRef]

68. Comisión Nacional del Agua (CONAGUA). Inventario Nacional de Plantas Municipales de Potabilización y de Tratamiento de Aguas Residuales en Operación; CONAGUA: Mexico City, Mexico, 2015. (In Spanish)

69. Fernández del Castillo, A.; Verduzco Garibay, M.; Senés-Guerrero, C.; Yebra-Montes, C.; de Anda, J.; Gradilla-Hernández, M.S. Mathematical modeling of a domestic wastewater treatment system combining a septic tank, an up flow anaerobic filter, and a constructed wetland. Water 2020, 12, 3019. [CrossRef]

70. Corominas, L.; Foley, J.; Guest, J.S.; Hospido, A.; Larsen, H.F.; Morera, S.; Shaw, A. Life cycle assessment applied to wastewater treatment: State of the art. Water Res. 2013, 47, 5480-5492. [CrossRef] [PubMed]

71. Laitinen, J.; Moliis, K.; Surakka, M. Resource efficient wastewater treatment in a developing area-Climate change impacts and economic feasibility. Ecol. Eng. 2017, 103. [CrossRef]

72. United Nations. Transforming our World: The 2030 Agenda for Sustainable Development. 2015. Available online: https://www. un.org/en/development/desa/population/migration/generalassembly/docs/globalcompact/A_RES_70_1_E.pdf (accessed on 14 February 2021).

73. Diario Tijuana (DTJ). Inicia el Proyecto Línea Morada para Riego de Áreas Verdes. DTJ. 25 May 2019. Available online: https:/ / diariotijuana.info/inicia-el-proyecto-linea-morada-para-riego-de-areas-verdes/ (accessed on 2 January 2021).

74. Arellano, J.M.T. Saneamiento Tijuana y Playas Rosarito. CESPT. 2012. Available online: http://www.conagua.gob.mx/ CONAGUA07/Contenido/Documentos/P2-Saneamiento\%20en\%20Tijuana\%20y\%20Playas\%20de\%20Rosarito, \%20Baja\%20 California.pdf (accessed on 2 January 2021).

75. Arellano, G. Se reúne CESPT con Gobiernos de Tijuana y Rosarito para Revisar Temas de Reuso de Agua. El Sol de Tijuana. 7 August 2020. Available online: https:/ / www.elsoldetijuana.com.mx/local/se-reune-cespt-con-gobiernos-de-tijuanay-rosarito-para-revisar-temas-de-reuso-de-agua-5596661.html (accessed on 2 January 2021).

76. Wasswa, J.; Mladenov, N.; Pearce, W. Assessing the potential of fluorescence spectroscopy to monitor contaminants in source waters and water reuse systems. Environ. Sci. Water Res. Technol. 2019, 5, 370-382. [CrossRef]

77. Mcknight, D.; Boyer, E.; Westerhoff, P.K.; Doran, P.T.; Kulbe, T.; Andersen, D. Spectrofluorometric characterization of dissolved organic matter for indication of precursor organic material and aromaticity. Limnol. Oceanogr. 2001, 46, 38-48. [CrossRef] 
78. Zsolnay, Á. Dissolved organic matter: Artefacts, definitions, and functions. Geoderma 2003, 113, 187-209. [CrossRef]

79. Weishaar, J.L.; Aiken, G.R.; Bergamaschi, B.; Fram, M.; Fujii, R.; Mopper, K. Evaluation of Specific Ultraviolet Absorbance as an Indicator of the Chemical Composition and Reactivity of Dissolved Organic Carbon. Environ. Sci. Technol. 2003, 37, 4702-4708. [CrossRef]

80. Mladenov, N.; Bigelow, A.; Pietruschka, B.; Palomo, M.; Buckley, C. Using submersible fluorescence sensors to track the removal of organic matter in decentralized wastewater treatment systems (DEWATS) in real time. Water Sci. Technol. 2017, 77, 819-828. [CrossRef] [PubMed] 